https://doi.org/10.15407/socium2020.01.123

UDC 336.711 .2

Shkliar A.I., PhD. (Economics), senior scientific fellow, Department for monetary relations, SO "Institute for Economics and Forecasting, National Academy of Sciences of Ukraine ", 26, Panasa Myrnoho Str., Kyiv,01011,Ukraine,email: Schkliar@nas.gov.ua

\title{
THE PHENOMENON OF CENTRAL BANKS' DIGITAL CURRENCIES (CBDC): KEY ATTRIBUTES AND IMPLEMENTATION PERSPECTIVES ${ }^{1}$
}

Paper dwells upon the phenomenon of the emergence of central banks' digital currencies (CBDC). Forms of digital money as means of exchange have been identified, and differences between central banks' digital currencies and other forms of central bank money such as physical money and reserves have been analyzed. Key causes of digital currency development by central banks were highlighted: the approach to the cashless economy, the fight against money laundering and tax evasion, the increasing competition of private digital currencies, the improvement of the monetary policy transmission mechanism, and technological advancement of the payment sector. Key differences between $C B D C$ and private digital currencies and physical currencies were analyzed and highlighted in terms of availability, anonymity, P2P transfers, interest-bearing features, and other possible limits. The main advantages of the CBDC were noted: stability and reliability, safety, speed and ease of use. At the same time, a list of prerequisites and factors that could enhance the benefits of central banks implementing their digital currencies were highlighted: more efficient retail payments, diminishing cash payments, strengthening the effectiveness of monetary policy and improving financial stability. Existing options for the design of the CBDC have been clarified, taking into account the technological aspect and the scope: "retail" for the general public and "wholesale" for financial institutions. Key warnings of the central banks of the world about the possible negative consequences of launching the $C B D C$ were noted, in particular, the disturbance of the financial system balance, when the flow of commercial bank clients to the central bank will force the first to raise deposit rates, which will eventually affect the cost of borrowing. The attitude of the key central banks of the world to the phenomenon of cryptocurrency development was noted, in particular, a much more positive attitude towards blockchain technology was observed compared to the position of the central banks on digital assets in general. At the same time, technological problems of blockchain technology in terms of its throughput capacity (number of transactions per unit of time) were noted, which is significantly inferior to other existing payment platforms. Central banks of the world have been grouped based on the $C B D C$ development principles, and public justifications for the need for CBDC implementation. The key ones being to reduce cash use and increase financial inclusion. The four existing options for the introduction of the CBDC were analyzed, each of which has individual features. The combined efforts of the world's central banks to study and test various aspects of the technical implementation of the CBDC in the form of joint projects were systematized.

Keywords: central bank digital currency (CBDC), Blockchain, distributed ledger technology, financial inclusion, monetary policy.

\footnotetext{
${ }^{1}$ This research is part of the scientific study "Financial services industry in terms of the "new reality" (state registration number 0118U003065).
}

(C) Shkliar A.I., 2020

ISSN 1681-116X. Ukrainian Society, 2020, № 1 (72): 123-137 
Shkliar A.I.

Шкляр А.І., канд. екон. наук, старший науковий співробітник відділу гротово-кредитних відносин ДУ “Інститут економіки та прогнозування НАН України”, вул. Панаса Мирного, 26, Київ, 01011, Україна, email: Schkliar@nas.gov.иа

\section{РОЗВИТОК ЦИФРОВИХ ВАЛЮТ ЦЕНТРАЛЬНИХ БАНКІВ ТА СТАВЛЕННЯ КЛЮЧОВИХ ЦЕНТРАЛЬНИХ БАНКІВ ДО ЇХ ВПРОВАДЖЕННЯ}

Розглянуто феномен виникнення иифрових валют иентральних банків (ЦВЦБ). Виокремлено форми цииррових громей як засобів обміну, а також проаналізовано відмінності циифрових валют центральних банків від інших форм громей центральних банків, зокрема фізичних грошей $і$ резервів. Виявлено причини створення циифрових валют центральними банками, головними серед яких є наближення до безготівкової економіки, боротьба з відмиванням грошей $і$ ухиленням від податків, зростаюча конкуренція приватних циифрових валют, покращення трансмісійного механізму монетарної політики, а також вища технологічність платіжних засобів. Проаналізовано та виокремлено ключові відмінності циифрових валют иентральних банків від приватних ичифрових валют $i$ фізичних валют, зокрема в розрізі доступності, анонімності, можсливості здійснення Р2Р-переказів, отримання відсотків на залишки по рахунку та інших обмежень. Визначено основні переваги ЦВЦБ: стабільність $i$ надійність, безпечність, швидкість та легкість використання. При иьому перелічено передумови та фактори, які могли б посилити переваги реалізації центральними банками власних цииррових валют, що спричинило б створення більш ефективних роздрібних платіжних інструментів, відхід від паперових грошей (принаймні крупних номіналів), посилення ефективності монетарної політики та підвищення фінансової стабільності. 3'ясовано існуючі опиії щзодо дизайну ЦВЦБ з урахуванням технологічного аспекту та сфери використання: “роздрібний” для иирокого загалу та “гуртовий” для фінансових інституиій. Визначено ключові перестороги фахівців иенттральних банків світу щңодо можсливих негативних наслідків запуску ЦВЦБ, зокрема, порушення балансу фінансової системи, коли відтік клієнтів комериійних банків до центрального банку змушуватиме перших піднімати депозитні ставки, щзо зрештою вплине на вартість запозичень реального сектору та з часом похитне стабільність фінансової системи. Виявлено ставлення ключових иентральних банків світу до феномену розвитку криптовалют, зокрема більш позитивне ставлення до технології блокчейн порівняно з позицією ЦБ щчодо циифрових активів у иілому. При ичьому порушено технологічні проблеми технології блокчейн у розрізі ї̈ пропускної здатності (кількості операцій за одиницю часу), що значно поступається іншим існуючим платіжсни платформам. Згруповано центральні банки світу за принципом мотивів щзодо розробки ЦВЦБ, а також зазначено публічні обтрунтування необхідності впровадження ЦВЦБ, головними з яких є зменшення використання готівки та підвищення фінансової інклюзї. Проведено порівняльний аналіз чотирьох існуючих опчій із запровадження ЦВЦБ, кожен з яких має індивідуальні характеристики щчодо подальшого використання ЦВЦБ. Систематизовано об'єднані зусилля центральних банків світу, щзо у формі спільних проєктів вивчають і тестують різні аспекти технологічної імплементації ЦВЦБ.

Ключові слова: цифррова валюта центрального банку, СВDС, блокчейн, технологія розподіленої книги, фінансова інклюзія, грошово-кредитна політика. 
The study by Bank for International Settlement ${ }^{2}$ confirmed that about 44 central banks of the world are working on plans to launch their cryptocurrency ${ }^{3}$. The first Bitcoin cryptocurrency appeared in 2009 as a payment tool for anonymous transactions. The first massive attempts to legitimize Bitcoin and other "coins" began with a boom in crypto assets in 2016-2017. Both companies with experience and market share and start-ups tried to introduce the new technology, but almost none of them achieved much success. The disadvantages of technology at that time became the reason for the skepticism of central banks about cryptocurrency perspectives.

The opinions of regulators began to change rapidly in June 2019, after Facebook introduced plans to create its own cryptocurrency Libra, able to provide 2 billion Facebook users access to financial instruments - transfers, loans, etc. Authorities realized that on a global scale, Libra could destroy the existing currency regimes, financial stability, and the ability of central banks to pursue the monetary policy. Thus, central banks began to work hard on their cryptocurrency projects.

In contrast to the first cryptocurrencies Bitcoin and Ethereum, which are very unstable and volatile (in a day they can lose 10-20\% of the price), Libra is designed as a stable $\operatorname{coin}^{4}$ (see Table 1). The prices of such currencies are tied to a certain asset that has low volatility. For example, one of the first stable coin Tether is pegged to the US dollar. Also, Facebook's gigantic infrastructure and financial resources are at the disposal of the Libra project, which increases its success opportunities.

Forms of digital currencies and means of exchange

\begin{tabular}{|c|c|}
\hline Form & Description \\
\hline Crypto-currencies & Privately issued token denominated in non-official currencies \\
\hline Stable coins & $\begin{array}{l}\text { Privately issued tokens backed by reservable assets and/or official } \\
\text { currencies }\end{array}$ \\
\hline Utility settlement coins & $\begin{array}{l}\text { Token issued by a consortium of private banks to serve as a vehicle to } \\
\text { intermediate intra-consortium flows. Can be backed by central bank } \\
\text { money }\end{array}$ \\
\hline $\begin{array}{l}\text { Central Banks Digital } \\
\text { Currency }\end{array}$ & Tokenized central bank money \\
\hline
\end{tabular}

Source: The (R)Evolution of Money II: Blockchain Empowered Central Bank Digital Currencies. (2019). Accenture. URL: https://www.accenture.com/_acnmedia/pdf-105/accenture-revolution-of-money-ii2019.pdf

On the other hand, according to a report by technology giant IBM and OMFIF (Official Monetary and Financial Institutions Forum), in addition to Libra, advances in financial technology have encouraged central banks to respond to emerging challenges from the private sector and address deficiencies in payment systems [1]. The report noted that after

\footnotetext{
2 This new form of currency could transform the way we see money. World Economic Forum 2019. URL: https://www.weforum.org/agenda/2019/04/this-new-form-of-currency-could-transform-the-way-we-see-money/

${ }^{3}$ Cryptocurrency - is the type of digital currency which uses cryptographic methods and blockchain technology. It can be centralized and decentralized.

${ }^{4}$ Stable Coin - type of cryptocurrency that is guaranteed by the official currency or other assets.
} 
the global financial crisis of 2008, consumers stopped trusting financial institutions. For example, in developed countries, the distrust of central banks is growing.

Central bank digital currency $(\boldsymbol{C B D C})$. To solve this problem, central banks are seriously considering the possibility of creating their digital currency, and according to the IBM and OMFIF report, the CBDC will be available for use by consumers by 2024. The digital currency of the central bank is an asset issued by the regulator for both retail and wholesale transactions. Retail CBDC can be used as a digital cash option for individuals and companies; wholesale CBDC can be used only by certain organizations as a settlement asset in the interbank market.

In general, CBDC would be the third form of central bank money, combining features of physical cash and central bank's deposit facility (see Table 2).

Table 2

Forms of Central Bank's Money

\begin{tabular}{|l|c|c|c|}
\cline { 2 - 4 } \multicolumn{1}{c|}{} & \multicolumn{1}{c|}{$\begin{array}{c}\text { Coins and bills } \\
\text { (physical cash) }\end{array}$} & Reserves & \multicolumn{2}{c|}{ CBDC } \\
\hline Retail users & $\sqrt{ }$ & $\sqrt{ }$ & $\sqrt{ }$ \\
\hline Wholesale users & $\sqrt{ }$ & $\sqrt{ }$ & $\sqrt{ }$ \\
\hline Digital form & & & \\
\hline
\end{tabular}

Source: Central Bank Digital Currency Policy-Maker Toolkit. (2019, January). Centre for the Fourth Industrial Revolution. World Economic Forum. URL: http://www3.weforum.org/docs/ WEF_CBDC_Policymaker_Toolkit.pdf

The central banks of China, Sweden and the Bahamas are among the pioneers of national cryptocurrencies development and implementation ${ }^{5}$. The National Bank of Ukraine in June 2019 also reported the results of the E-hryvnia pilot project and confirmed the desire to further explore the digital currency opportunities in Ukraine [2]. Most countries are in no hurry to develop their cryptocurrency, but they are watching the situation - especially in matters of cybersecurity and the demand for such an instrument. In general, CBDC implementation is attractive for central banks for several reasons (see Table 3).

In an attempt to foresee the macroeconomic implications of adopting the CBDC, central banks are faced with a lack of historical experience. Central banks fear that if the use of fiat money is significantly reduced, the monetary policy of the central bank will depend on the policy of the issuer of electronic money, which could seriously weaken the monetary policy efficiency, as well as limit the ability of the central bank to act as a lender of last resort. The issuance of the central bank's digital currency may prevent such competition if it replaces private electronic money.

In the case of CBDC implementation, the monetary policy would be a much more direct tool, being more efficient, allowing central banks to introduce negative interest rates widely when necessary, and provide the market with unlimited safe assets. This paves the way for the release of state cryptocurrencies for global payments.

\footnotetext{
${ }^{5}$ Marsh, A. (2019, October 20). Why Central Bankers Got Serious About Digital Cash. Bloomberg. URL: https://www.bloomberg.com/news/articles/2019-10-20/why-central-bankers-got-serious-about-digital-cashquicktake
} 
Table 3

Reasons for CBDC implementation

\begin{tabular}{|l|l|}
\hline \multicolumn{1}{|c|}{ Reason } & \multicolumn{1}{|c|}{ Description } \\
\hline $\begin{array}{l}\text { Dwindling use of cash } \\
\text { (absolute and/or relative) }\end{array}$ & $\begin{array}{l}\text { The decreasing significance of cash for transactions means that there is a } \\
\text { conceivable scenario of having a society without general access to central } \\
\text { bank money. This might be not desirable for political reasons (as e. g. } \\
\text { banks are given too much power) }\end{array}$ \\
\hline $\begin{array}{l}\text { Combatting tax } \\
\text { evasion/money laundering }\end{array}$ & $\begin{array}{l}\text { Increasing the effectiveness of the tax and social security system. Risk of } \\
\text { evasive actions like dollarization }\end{array}$ \\
\hline $\begin{array}{l}\text { CBDC as an accelerator } \\
\text { towards a cashless society }\end{array}$ & $\begin{array}{l}\text { Costs involving the handling of cash would be cut. Risk: Unclear if } \\
\text { CBDC is attractive for people or if the forced introduction of CBDC and } \\
\text { elimination of cash would lead to harmful side effects }\end{array}$ \\
\hline $\begin{array}{l}\text { Competition with } \\
\text { cryptocurrencies }\end{array}$ & $\begin{array}{l}\text { CBDC would cut out banks as intermediaries, making it more competitive } \\
\text { to cryptocurrencies which enable peer-to-peer transfers (albeit at a low } \\
\text { scale) }\end{array}$ \\
\hline $\begin{array}{l}\text { Zero lower bound/monetary } \\
\text { transmission process }\end{array}$ & $\begin{array}{l}\text { The elimination of the zero lower bound happens only when cash would } \\
\text { be eliminated. In the case of Ukraine, this point is less relevant at the } \\
\text { moment due to rather high inflation and interest rates }\end{array}$ \\
\hline $\begin{array}{l}\text { More efficiency/higher } \\
\text { welfare }\end{array}$ & $\begin{array}{l}\text { Cutting out banks as middlemen would correspond to the evolution of the } \\
\text { internet economy, whose role has increased significantly over the last } \\
\text { years }\end{array}$ \\
\hline Technological feasibility & $\begin{array}{l}\text { While certain designs of CBDC are rather complex, the progress of the } \\
\text { last decades means that the technological borders have been expanded }\end{array}$ \\
\hline
\end{tabular}

There would be less space for tax evasion, as all transactions will be monitored. Besides, the power of the international financial system would be decreased that would be beneficial for the governments of countries that are faced with international sanctions. But the CBDC issue, by definition, would force central banks to do everything from reviewing public complaints and user requests to "know your customer" and anti-money laundering checks. Due to the lack of experience, there is no guarantee that they will be able to cope with this work at a lower cost and more efficiently than the main banking sector.

The difference of $\mathrm{CBDC}$ from other digital currencies. When comparing $\mathrm{CBDC}$ to other digital currencies used as means of payment (Bitcoin (BTC), Ethereum (ETH), etc.), the central bank's cryptocurrency, unlike the latter, will be secured and guaranteed by the national banks of the countries that issue them. At the same time, CBDC differs from official currencies in that it will exist only in the digital form.

At the same time, like official currencies, CBDC will act as a means of payment, a means of accumulation and a measure of value. Another feature of the CBDC is the direct connection of the user with the central bank, allowing the transactions to occur without the mediation of commercial banks, unlike the existing cashless payments [3].

Meanwhile, the peculiarities of the monetary policy and financial stability implications would be much dependent on the design of the CBDC (see Table 4). 
Table 4

Key Design Features of Central Bank's Money

\begin{tabular}{|c|c|c|c|c|c|}
\hline & \multicolumn{2}{|c|}{ Existing central bank money } & \multicolumn{3}{|c|}{ CBDC } \\
\hline & \multirow{2}{*}{ Cash } & \multirow{2}{*}{$\begin{array}{c}\text { Reserves and settlement } \\
\text { balances }\end{array}$} & \multicolumn{2}{|c|}{ Retail } & \multirow{2}{*}{$\begin{array}{l}\text { Wholesale only } \\
\text { token }\end{array}$} \\
\hline & & & token & account & \\
\hline 24/7 availability & $\sqrt{ }$ & $\mathrm{x}$ & $\sqrt{ }$ & $(\sqrt{ })$ & $(\sqrt{ })$ \\
\hline Anonymity for $\mathrm{CB}$ & $\sqrt{ }$ & $\mathrm{x}$ & $(\sqrt{ })$ & $\mathrm{X}$ & $(\sqrt{ })$ \\
\hline Peer-to-peer transfer & $\sqrt{ }$ & $\mathrm{x}$ & $(\sqrt{ })$ & $\mathrm{x}$ & $(\sqrt{ })$ \\
\hline Interest-bearing & $\mathrm{x}$ & $(\sqrt{ })$ & $(\sqrt{)}$ & $(\sqrt{ })$ & $(\sqrt{)}$ \\
\hline Limits or caps & $\mathrm{x}$ & $\mathrm{x}$ & $(\sqrt{ })$ & $(\sqrt{ })$ & $(\sqrt{ })$ \\
\hline
\end{tabular}

Note: $\sqrt{ }$ - existing or likely feature; $(\sqrt{ })$ - possible feature; $\mathrm{x}$ - not typical or possible feature.

Source: Key Aspects around Central Bank Digital Currencies. Policy report. (2019, May). Central Bank Digital Currencies Working Group (CBDC WG), CELMA. URL: https://www.cemla.org/fintech/docs/ 2019-06-KeyAspectsAroundBankDigitalCurrencies.pdf

Table 5

Benefits of CBDC and related factors and requirements

\begin{tabular}{|c|c|c|}
\hline Argument & Benefit of CBDC & Possible further factors or requirements \\
\hline \multirow{2}{*}{$\begin{array}{l}\text { A. Efficient retail } \\
\text { payments }\end{array}$} & $\begin{array}{l}\text { A.1. Making available efficient, secure } \\
\text { and modern central bank money to } \\
\text { everyone }\end{array}$ & $\begin{array}{l}\text { In particular in economies without high- } \\
\text { quality electronic commercial bank } \\
\text { money, and/or without a secure and } \\
\text { efficient payment system }\end{array}$ \\
\hline & $\begin{array}{l}\text { A.2. Strengthening the resilience, } \\
\text { availability, and contestability of retail } \\
\text { payments }\end{array}$ & $\begin{array}{l}\text { In particular in economies in which } \\
\text { banknote demand vanishes and private } \\
\text { electronic payments solutions lack } \\
\text { competition }\end{array}$ \\
\hline $\begin{array}{l}\text { B. Overcome the } \\
\text { use of banknotes for } \\
\text { illicit payment and } \\
\text { store of value }\end{array}$ & $\begin{array}{l}\text { B. Better control of illicit payment and } \\
\text { saving activities, money laundering, } \\
\text { and terrorist financing }\end{array}$ & $\begin{array}{l}\text { Requires (i) discontinuation of banknotes } \\
\text { (or at least of larger denominations); (ii) } \\
\text { CBDC to not take the form of anonymous } \\
\text { token money }\end{array}$ \\
\hline \multirow{3}{*}{$\begin{array}{l}\text { C. Strengthen } \\
\text { monetary policy }\end{array}$} & $\begin{array}{l}\text { C.1. Allows overcoming the ZLB as } \\
\text { negative interest rates can be applied to } \\
\text { CBDC }\end{array}$ & $\begin{array}{l}\text { Requires discontinuation of banknotes (or } \\
\text { at least of larger denominations) }\end{array}$ \\
\hline & $\begin{array}{l}\text { C.2. Interest rates on CBDC provide } \\
\text { for additional monetary policy } \\
\text { instruments, independently of ZLB }\end{array}$ & \\
\hline & $\begin{array}{l}\text { C.3. Easier ability to provide } \\
\text { helicopter money }\end{array}$ & $\begin{array}{l}\text { Requires that each citizen has a CBDC } \\
\text { account }\end{array}$ \\
\hline \multirow[t]{2}{*}{$\begin{array}{l}\text { D. Sovereign money } \\
\text { related }\end{array}$} & $\begin{array}{l}\text { D.1. Improve financial stability and } \\
\text { reduce the moral hazard of banks by } \\
\text { downscaling the role of the banking } \\
\text { system in money creation }\end{array}$ & $\begin{array}{l}\text { CBDC takes over to large or full extent } \\
\text { sight deposit issuance by banks }\end{array}$ \\
\hline & $\begin{array}{l}\text { D.2. Larger seignorage income to state } \\
\text { (and citizens) as the state takes back } \\
\text { money creation from banks }\end{array}$ & $\begin{array}{l}\text { CBDC takes over to large or full extent } \\
\text { sight deposit issuance by banks }\end{array}$ \\
\hline
\end{tabular}

Source: Bindseil, U. (2020, January). Tiered CBDC and the financial system. Working Paper Series. No. 2351. ECB. URL: https://www.ecb.europa.eu/pub/pdf/scpwps/ecb.wp2351 c8c18bbd60.en.pdf 
The general advantages of $C B D C$ can be defined as the following [3]:

1) stability and reliability, as the issue will be handled exclusively by the national central bank;

2) security, both technical and financial;

3) speed and ease of use, including the speed of transaction and its availability for the population.

The more detailed structure of CBDC benefits is made by ECB, but with the stress on the demanded factors and requirements to be provided (see Table 5).

In light of the above features, CBDC supporters believe that in the long run, they should completely displace both cash and cryptocurrency payments, becoming one of the world's major payment methods. A report from the World Economic Forum shows that small investors are to place cryptocurrency savings if they are allowed to open accounts with central banks. Also, the CBDC will help reduce prices for banking services and attract about 1.7 billion customers [4].

But despite the obvious advantages of the central bank's cryptocurrencies, there are still obstacles to their global deployment.

Disadvantages of CBDC and risks for the banking sector. In respect of CBDC, 73\% of the polled by IBM and OMFIF representatives of the regulators were sure that there is no other way either the creation of the CBDC. At the same time, the absolute majority of surveyed central banks is confident that such digital assets can create risks for existing banks since operations with them can begin to replace standard operations of financial institutions [1]. There are two main unclear and potentially risk-bearing issues of the CBDC implementation.

First, it is not completely clear what the CBDC will look like. There are several possible concepts for its introduction to the financial system (see Figure 1). In the first case, the "wholesale" CBDC will only be available to commercial banks. The goal is to ensure that cash flows in the existing financial system move faster and transfers are cheaper. But such an option excludes all the benefits of CBDC implementation. The second option, "retail" CBDC will be available to all individuals and legal entities. The central bank will issue CBDC through an account for the general public or an account with a commercial bank working with the central bank. The regulator will check clients, enforce the law on combating money laundering and share information with the tax office.

Modern CBDC also explores the most useful features of Bitcoin and other digital currencies, based on the distributed ledger technology (DLT). It lets central banks design the control over the future CBDC, as blockchain technology alone does not preclude the possibility of centralization, even when until now many digital currencies consciously developed as decentralized projects. Moreover, the central banks will control the digital currency much better than paper currency, as it will be able to track absolutely all transactions. Both options of CBDC are extending the frontiers of the central banks' money (see Figure 2). 


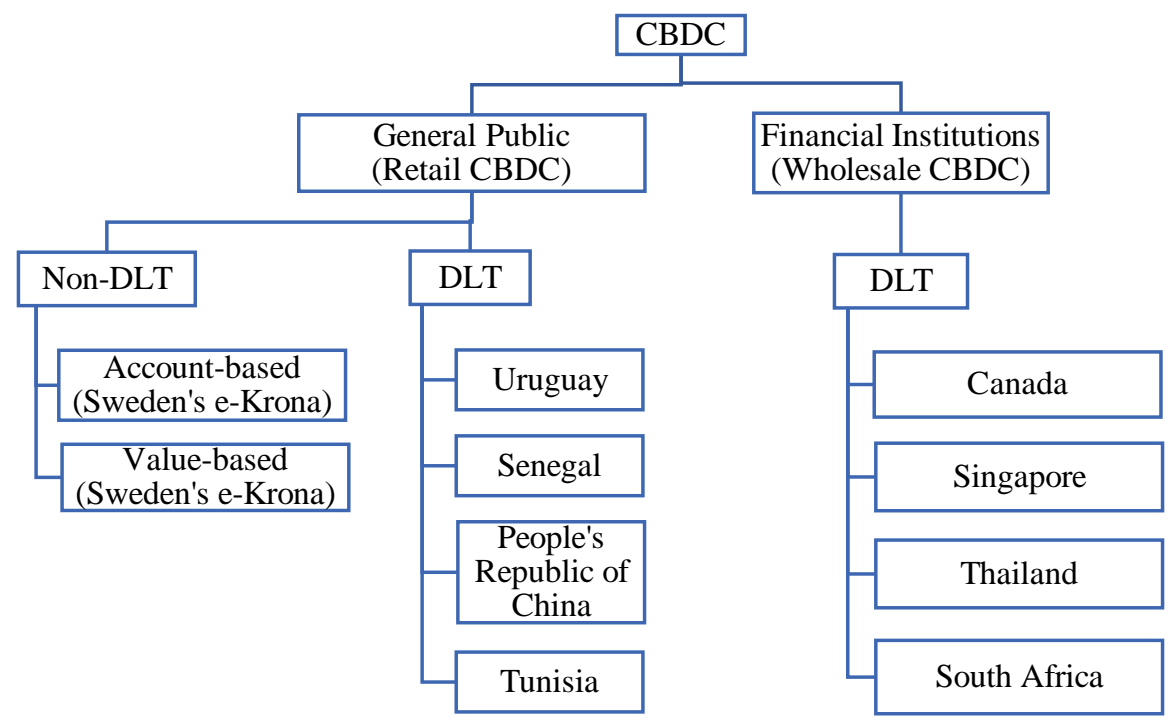

Figure 1. Proposals of Retail and Wholesale CBDC

Source: Shirai, S. (2019, February). Money and Central Bank Digital Currency. ADBI Working Paper Series. No. 922. Asian Development Bank Institute. URL: https://www.adb.org/sites/default/ files/publication/485856/adbi-wp922.pdf

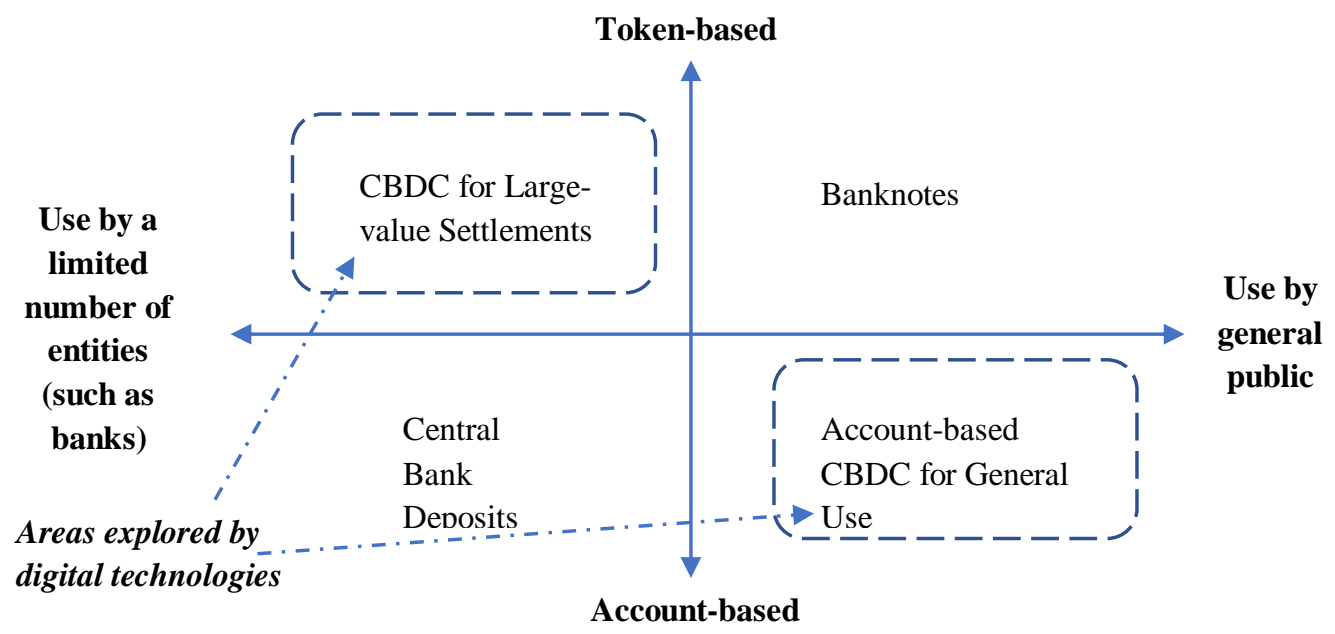

Figure 2. The frontiers of the central bank's money

Source: Yanagawa, N., Yamaoka, H. (2019, February). Digital Innovation, Data Revolution and Central Bank Digital Currency. Working Paper Series. No.19-E-2. Bank of Japan. URL: https://www.boj.or.jp/en/research/wps_rev/wps_2019/data/wp19e02.pdf 
Secondly, the CBDC has not yet been widely launched and finds many critics and skeptics. One of the strongest warnings is that the introduction of the CBDC will disrupt the financial balance because under such a system the central bank will easily be able to lure commercial bank customers to themselves. This, in turn, will force banks to raise interest rates on deposits to retain customers, as well as raise interest rates on loans to maintain the margin of their businesses. All of this can have a serious impact on the stability of the entire financial sector.

Central bank's attitude to digital currencies and CBDC. The important issue is the attitude of central banks to digital assets in general and CBDC in particular. According to the IBM and the OMFIF study, central banks fear that the spread of digital assets will lead to such a level of change in the quality of financial transactions that it can lead to a significant outflow of customers from banks and their transition to cooperation with cryptocurrency infrastructure institutions [1]. The study interviewed representatives of 23 central banks, with 13 representing regulators of advanced economies, and 10 representing emerging economies. All of them made a statement that private cryptocurrencies pose a threat to financial stability. With all this concern, researchers believe that central banks generally advocate the digitalization of payment channels, but only so that it has a limited scope. That is so that this does not affect large volumes of financial transactions, as well as interbank relations.

Worth to say that central banks, in general, have a pretty different attitude to cryptocurrencies and blockchain technology (see Tables 6,7).

Central banks' positions towards cryptocurrencies and digital assets*

\begin{tabular}{|l|l|}
\hline \multicolumn{1}{|c|}{ Position } & \multicolumn{1}{c|}{ Central banks } \\
\hline Generally negative view & $\begin{array}{l}\text { Azerbaijan, Australia, Bank for International Settlements, Canada, China, } \\
\text { European Central Bank, Finland, France, Hong Kong, India, Indonesia, } \\
\text { Japan, Malaysia, Netherlands, New Zealand, Norway, Russia, South Africa, } \\
\text { South Korea, Switzerland, United Kingdom, USA }\end{array}$ \\
\hline Policy: Ban & China, India, Indonesia, Morocco, South Korea, Thailand \\
\hline Policy: Monitor & $\begin{array}{l}\text { No real risk to financial stability: Australia, India, United Kingdom, USA. } \\
\text { Ready if the action required: Brazil, Malaysia, Russia, Singapore, } \\
\text { Switzerland, United Kingdom. } \\
\text { Issued investor warnings: Canada, China, France (Bitcoin), ECB, Germany, } \\
\text { Hong Kong, United Kingdom }\end{array}$ \\
\hline Policy: Regulate & $\begin{array}{l}\text { Integrate into the existing financial regulatory framework: Canada, Hong } \\
\text { Kong, Indonesia, Japan, Mauritius, Singapore, USA. } \\
\text { New regulatory framework: France (ICOs), Gibraltar, Japan, Mauritius, } \\
\text { Thailand. } \\
\text { Consulting on regulations: Israel, Russia, South Africa }\end{array}$ \\
\hline Policy: Support & $\begin{array}{l}\text { Brazil, Japan, Malta, Sweden, Venezuela, Bermuda, Germany, Israel, } \\
\text { Switzerland, Ukraine }\end{array}$ \\
\hline
\end{tabular}

* As of January 2019.

Source: Ward, O., Rochemont, S. (2019, March). Understanding Central Bank Digital Currencies (CBDC). An addendum to "A Cashless Society- Benefits, Risks and Issues (Interim paper)". Institute and Faculty of Actuaries. URL: https://www.actuaries.org.uk/documents/understanding-central-bank-digital-currencies-cbdc 
Central banks' positions towards Blockchain*

\begin{tabular}{|l|l|}
\hline \multicolumn{1}{|c|}{ Position } & \multicolumn{1}{c|}{ Central banks } \\
\hline $\begin{array}{l}\text { Recognize the potential } \\
\text { public utility }\end{array}$ & Canada, Bahamas, Eastern Caribbean, Russia, Turkey, Kenya. \\
\hline $\begin{array}{l}\text { Technology limitations are } \\
\text { a barrier to adoption }\end{array}$ & $\begin{array}{l}\text { Canada, China, ECB, Germany, Netherlands, Hong Kong, Japan, Norway, } \\
\text { South Africa, South Korea, USA. }\end{array}$ \\
\hline $\begin{array}{l}\text { Blockchain friendly } \\
\text { countries }\end{array}$ & France, Hong Kong, Kazakhstan, New Zealand, South Korea. \\
\hline
\end{tabular}

* As of January 2019.

Source: Ward, O., Rochemont, S. (2019, March). Understanding Central Bank Digital Currencies (CBDC). An addendum to "A Cashless Society- Benefits, Risks and Issues (Interim paper)". Institute and Faculty of Actuaries. URL: https://www.actuaries.org.uk/documents/understanding-central-bank-digital-currencies-cbdc

At the same time, central banks were less critical to blockchain technology, recognizing its potential though mentioning technology architecture as the limiting factor for blockchain wide implementation.

While Bitcoin was created in protest against financial authorities and was aimed at ensuring anonymity, now central banks intend to use the blockchain to control transactions. The weakest point of the plan is the blockchain technology's limited capacity of transactions per second. According to the latest data, in terms of the total number of transactions for the year, Bitcoin seriously lags behind Visa and MasterCard with 81 million transactions against 124 billion and 74 billion transactions, respectively.

A study by the People's Bank of China showed that both Bitcoin and Ethereum have poor performance of fewer than 20 transactions per second (see Figure 3), while Libra may pretend on 1000 transactions per second. That is still not enough compared to 24,000 transactions per second by Visa and peak demand of Chinese consumers of 92,771 transactions per second reported on Single's Day in 2019 [5].

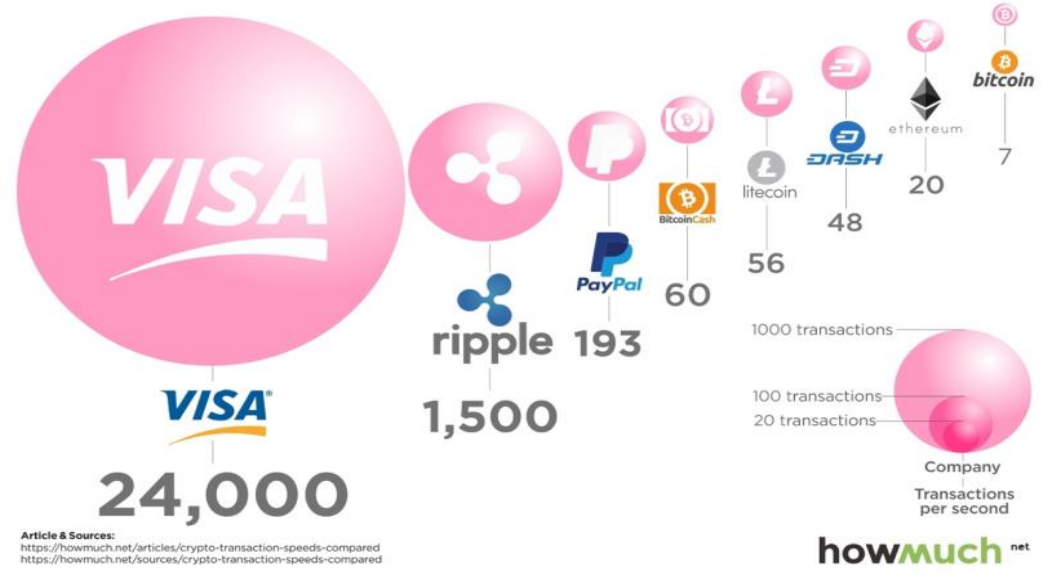

Figure 3. Transaction speed comparison: cryptocurrencies vs Visa and PayPal

Source: Ward, O., Rochemont, S. (2019, March). Understanding Central Bank Digital Currencies (CBDC). An addendum to "A Cashless Society- Benefits, Risks and Issues (Interim paper)". Institute and Faculty of Actuaries. URL: https://www.actuaries.org.uk/documents/understanding-central-bank-digital-currencies-cbdc 
The active development of the national cryptocurrencies will also impact the influence of the Federal Reserve System and the European Central Bank (ECB) - two main traditional central banks, which are currently controlling the world financial system. Having both decided against planning to implement own CBDC, ECB is continuing studies for the exploration of the long-term potential of CBDC (see Table 8).

Central banks' positions towards CBDC*

Table 8

\begin{tabular}{|c|c|}
\hline Position & Central banks \\
\hline $\begin{array}{l}\text { Recognize the potential } \\
\text { value of CBDCs }\end{array}$ & $\begin{array}{l}\text { Maintain public access to Central Bank liability in event of declining use of } \\
\text { cash: Norway, Sweden. } \\
\text { Facilitate de-cashing: Curaçao and Sint Maarten, Israel. } \\
\text { Improve cross border transaction systems: Canada, Hong Kong, Saudi } \\
\text { Arabia, Singapore, United Kingdom. } \\
\text { Modernize interbank settlement systems: BIS, Singapore, Thailand. } \\
\text { Address underserved markets: Bahamas }\end{array}$ \\
\hline $\begin{array}{l}\text { Have decided against } \\
\text { planning to implement } \\
\text { CBDC }\end{array}$ & $\begin{array}{l}\text { Azerbaijan, Australia, Denmark, ECB, Estonia, Germany, Hong Kong, } \\
\text { India, Israel, Japan, New Zealand, Norway, South Korea, Switzerland, USA }\end{array}$ \\
\hline $\begin{array}{l}\text { Continue studies for long } \\
\text { term potential }\end{array}$ & $\begin{array}{l}\text { Brazil, Canada, China, Indonesia, Israel, Norway, Singapore, UAE, United } \\
\text { Kingdom, USA, ECB, and Japan (financial market infrastructure) }\end{array}$ \\
\hline $\begin{array}{l}\text { Are actively developing } \\
\text { experiments, trials }\end{array}$ & $\begin{array}{l}\text { Bahamas, Eastern Caribbean, Kazakhstan, Philippines, Russia, South } \\
\text { Africa, Sweden, Thailand, Ukraine, UAE, Uruguay }\end{array}$ \\
\hline CBDC operational & Iran, Marshall Islands, Senegal, Tunisia, Venezuela \\
\hline CBDC decommissioned & Ecuador \\
\hline \multicolumn{2}{|l|}{ * As of January 2019.} \\
\hline \multicolumn{2}{|c|}{$\begin{array}{l}\text { Source: Ward, O., Rochemont, S. (2019, March). Understanding Central Bank Digital Currencies } \\
\text { (CBDC). An addendum to "A Cashless Society- Benefits, Risks and Issues (Interim paper)". Institute } \\
\text { and Faculty of Actuaries. URL: https://www.actuaries.org.uk/documents/understanding-central-bank- } \\
\text { digital-currencies-cbdc }\end{array}$} \\
\hline
\end{tabular}

In general, all countries, planning to implement the CBDC, can be divided into 2 categories. The first category is highly developed countries, which are gradually moving away from cash and looking for an alternative. One of the reasons is the economic benefit of going out of circulation (printing and processing) of cash. This category includes Sweden, Canada, China, and Norway. The second category is countries with economic problems. It is beneficial for these countries to bring new technologies to the market to combat inflation and economic crises. This group includes Thailand, Venezuela, Uruguay and the like.

The CBDC idea is especially popular among authoritarian regimes that want to evade international sanctions. The United States imposes sanctions on banks and companies that, as part of the American financial system, conduct business with a particular country. Violators are tracked by transactions in the international banking system. But if the government had its cryptocurrency, the American authorities would not be able to track the transactions conducted in it. The same effect can be achieved using Bitcoin or other digital currency, but it may be difficult for the government to get enough of this cryptocurrency, and additionally, such central banks are afraid of the high volatility of exchange rate of such currencies. 
The soundest case of sanctions driven CBDC is a project called El Petro. Venezuelan President Nicolas Maduro introduced a national cryptocurrency - each unit is to be backed with one barrel of oil. On the background of the dollar deficit resulting from US sanctions, the introduction of El Petro was expected to help Venezuela gain access to foreign exchange, goods and services from around the world. But the project failed: firstly, there was no mechanism for exchanging cryptocurrency for oil or other physical assets, as envisaged by the Maduro plan, and secondly, the Venezuelan parliament, controlled by the opposition, declared El Petro illegal currency.

The Eastern Caribbean Central Bank, which provides policy for 8 island states, have already launched their cryptocurrency in March 2019. At the end of 2019, the pilot mode of own CBDC was launched by the Central Bank of the Bahamas.

Meanwhile, the Central Banks of Sweden, Great Britain, Germany, Spain, Switzerland, China, Canada, India, South Africa, and the Netherlands at one time or another have shown interest in CBDC, keeping an eye on its developments.

In Sweden, where cash is being used less and less, Riksbank is developing its cryptocurrency called E-krona since 2017, fearing that widespread use of other digital currencies controlled by private organizations could adversely affect the country's competitiveness.

The Swiss National Bank with the SIX Stock Exchange is exploring how to introduce central bank cryptocurrency into trading and settlements between financial market participants.

Despite the European leadership in trials and research of the CBDC issue, the People's Bank of China is likely to be the first in the world to introduce a national cryptocurrency on a large scale. In August 2019, after five years of research, the regulator announced that China would soon have its digital currency, which could be issued in conjunction with Chinese commercial enterprises.

It must be said that many countries categorically refused to create their digital currency. Denmark, for example, believes that CBDC will not improve anything in existing cashless payment solutions, but it is likely to increase the risks of financial stability.

On the other side, there is a big group of countries which took a wait and see attitude. Central banks of Russia and the US Federal Reserve System are in no hurry to introduce their cryptocurrency. The Central Bank of Japan and the Deutsche Bundesbank also share this approach looking upon the results of the ongoing researches.

The publicly articulated motives of key central banks in CBDC development are also pretty different and reflect their level of development and scope of existing challenges they are tackling (see Table 9).

The diverse is also CBDC design, proposed by central banks. So far there are 4 options of proposals with a specific set of features (see Table 10).

Worth to say, that pioneers of CBDC development tend to unite forces for joint exploration of the topic. Since 2018 central banks of different countries were united in several projects to test and validate different aspects of CBDC implementation (see Table 11). 
Table 9

Rationales for CBDC implementation

\begin{tabular}{|c|c|c|c|c|}
\hline & \multicolumn{2}{|c|}{ Diminishing cash usage } & \multirow{2}{*}{ Cost efficiency } & \multirow{2}{*}{$\begin{array}{l}\text { Financial } \\
\text { inclusion }\end{array}$} \\
\hline & Monopoly distortions & Operational risks & & \\
\hline Bahamas & & & & $\sqrt{ }$ \\
\hline Canada & $\sqrt{ }$ & & & \\
\hline China & $\sqrt{ }$ & $\sqrt{ }$ & $\sqrt{ }$ & $\sqrt{ }$ \\
\hline ECCB & & $\sqrt{ }$ & $\sqrt{ }$ & $\sqrt{ }$ \\
\hline Ecuador & & & $\sqrt{ }$ & \\
\hline Norway & $\sqrt{ }$ & & & \\
\hline Senegal & & & & $\sqrt{ }$ \\
\hline Sweden & $\sqrt{ }$ & $\sqrt{ }$ & & \\
\hline Tunisia & & & & $\sqrt{ }$ \\
\hline Uruguay & & & $\sqrt{ }$ & $\sqrt{ }$ \\
\hline
\end{tabular}

* According to the publicly available information.

Source: Casting Light on Central Bank Digital Currency. (2018, November). IMF staff discussion note. SDN 18/08. IMF. URL: https://www.imf.org/ /media/Files/Publications/SDN/2018/SDN1808.ashx

Table 10

Features of Central Bank Digital Currency Proposals

\begin{tabular}{|c|c|c|c|c|}
\hline & Proposal 1 & Proposal 2 & Proposal 3 & Proposal 4 \\
\hline Type & Account-based & Value-based & Digital Token & Digital Token \\
\hline Technology & Non-DLT & Non-DLT & DLT & DLT \\
\hline Scope & Retail & Retail & Retail & Wholesale \\
\hline General public & $\sqrt{ }$ & $\sqrt{ }$ & $\sqrt{ }$ & $\mathrm{x}$ \\
\hline Anonymous & $\mathrm{x}$ & $(\sqrt{ })$ & $\sqrt{ }$ & $\sqrt{ }$ \\
\hline Traceable & $\sqrt{ }$ & $\sqrt{ }$ & $\sqrt{ }$ & $\sqrt{ }$ \\
\hline Peer-to-peer & $\mathrm{x}$ & $(\sqrt{ })$ & $(\sqrt{ })$ & $(\sqrt{ })$ \\
\hline $24 \mathrm{~h} / 365$ days & $\sqrt{ }$ & $\sqrt{ }$ & $\sqrt{ }$ & $\sqrt{ }$ \\
\hline Interest rate & $\sqrt{ }$ & $(\sqrt{ })$ & $\sqrt{ }$ & $\sqrt{ }$ \\
\hline Countries & Sweden & Sweden & Uruguay & $\begin{array}{c}\text { Canada, Singapore, } \\
\text { South Africa, } \\
\text { Thailand, } \\
\text { Eurozone-Japan }\end{array}$ \\
\hline
\end{tabular}

Note: $\sqrt{ }$ - existing feature; $(\sqrt{ })$ - possible feature; $\mathrm{x}$ - unavailable feature.

Source: Shirai, S. (2019, February). Money and Central Bank Digital Currency. ADBI Working Paper Series, No. 922. Asian Development Bank Institute. URL: https://www.adb.org/sites/default/files/ publication/485856/adbi-wp922.pdf

Later, in mid-January 2020, six central banks formed a working group with the Bank for International Settlements (BIS) to exchange information on the issue of cryptocurrency. The group will include the central banks of Sweden, Canada, Switzerland, Great Britain, and Japan, as well as the European Central Bank (ECB) and BIS. Each institution will continue to evaluate the "economic, functional and technical options for issuing digital currency by the central bank" and share its findings with the rest [6]. 
Central banks' joint projects on CBDC research

\begin{tabular}{|l|l|l|}
\hline \multicolumn{1}{|c|}{ Project } & \multicolumn{1}{|c|}{ Members } & \multicolumn{1}{c|}{ Outcome } \\
\hline E-krona & $\begin{array}{l}\text { Central Bank of } \\
\text { Sweden (2019) }\end{array}$ & $\begin{array}{l}\text { The first stage of the project (2018) concluded that E-krona is } \\
\text { compatible with the Riksbank's task to promote a safe and efficient } \\
\text { payment system. The Riksbank is working on the development of } \\
\text { E-krona for the non-bank public. }\end{array}$ \\
\hline Stella & $\begin{array}{l}\text { Bank of Japan, } \\
\text { European Central } \\
\text { Bank (2019) }\end{array}$ & $\begin{array}{l}\text { The project proved that distributed ledger technologies may bring } \\
\text { improvements to the safety of cross border payments. }\end{array}$ \\
\hline $\begin{array}{l}\text { Project } \\
\text { Jasper-Ubin } \\
\text { ECCB CBDC } \\
\text { pilot }\end{array}$ & $\begin{array}{l}\text { Bonk of Canada, } \\
\text { of Singapore (2019) }\end{array}$ & $\begin{array}{l}\text { Eastern Caribbean } \\
\text { Central Bank (2019) } \\
\text { cross-border payments by an exchange of wholesale CBDC across } \\
\text { different DL platforms. }\end{array}$ \\
\hline $\begin{array}{l}\text { The ECCB introduced a digital version of the EC dollar (DXCD) } \\
\text { based on blockchain to be used as a generalized medium of } \\
\text { payment to reduce cash usage by 50 percent, promote greater } \\
\text { financial sector stability and support economic growth and } \\
\text { development. }\end{array}$ \\
\hline $\begin{array}{l}\text { Interbank } \\
\text { Payments and } \\
\text { Settlements }\end{array}$ & $\begin{array}{l}\text { Bank of Canada, } \\
\text { Bank of England, } \\
\text { Monetary Authority } \\
\text { of Singapore (2018) }\end{array}$ & $\begin{array}{l}\text { The project results show that blockchain-enabled platforms offer } \\
\text { the possibility of a shift away from the existing correspondent } \\
\text { banking model and extend availability and payment tracking. }\end{array}$ \\
\hline Jasper III & $\begin{array}{l}\text { Bank of Canada, } \\
\text { Payments Canada, } \\
\text { TMX (2018) }\end{array}$ & $\begin{array}{l}\text { The proof of concept demonstrated that a blockchain-based system } \\
\text { can improve settlement and result in the ability to instantly reuse } \\
\text { cash and equity tokens reducing liquidity needs. }\end{array}$ \\
\hline
\end{tabular}

Source: The (R)Evolution of Money II: Blockchain Empowered Central Bank Digital Currencies. (2019). Accenture. URL: https://www.accenture.com/_acnmedia/pdf-105/accenture-revolution-of-money-ii2019.pdf

Members of the group will also work closely with the Committee on Payments and Market Infrastructure (CPMI), the international developer of standards for payments and clearing, and the Financial Stability Board (FSB), the body that makes recommendations for the global financial system, which previously warned of the potential risks of using cryptocurrencies.

Conclusions. If central banks can overcome technical difficulties, CBDC can provide faster and cheaper international money transfers and improve access to legal means of payment in countries where cash supplies are declining.

The World Economic Forum report indicated that new CBDC could offer retail investors safer places to save if it allowed them to create accounts at their central bank, and could lower price barriers that would impact financial inclusion and improve access to banking services.

The monetary policy is expected to become more efficient by allowing the direct transfer of interest rates. On the other hand, it can also give the government an additional tool for control over illegal activities. It can be possible if central banks can take responsibility for conducting due diligence on clients, fulfilling anti-money laundering and anti-terrorism financing requirements, and providing tax information to tax authorities. 
So far there is no CBDC implementation by the central bank of the considerable scale. Considering the public announcements, the first could be the central bank of China, looking for stricter control over the segment of digital currencies. Depending on the success of the first big CBDC implementation, the following design of the upcoming CBDC would be adopted.

\section{References}

1. Retail CBDCs: The next payments frontier. (2019). IBM, OMFIF. URL: https://www.omfif.org/ wp-content/uploads/2019/11/Retail-CBDCs-The-next-payments-frontier.pdf

2. Naitonal Bank Will Continue to Look into Possibility of Issuing Its Own Digital Currency - the E-hryvnia. (2019, June). National Bank of Ukraine. URL: https://bank.gov.ua/news/all/natsionalniy-bankprodovjit-vivchati-mojlivist-vipusku-vlasnoyi-tsifrovoyi-valyuti--e-grivni [in Ukrainian]

3. Synytsia, O. (2019, September 20). Cryptocurrency of Central Banks - nearest future or science fiction. NV. URL: https://nv.ua/ukr/techno/technoblogs/kriptovalyuta-centrobankov-blizhaysheebudushchee-ili-nauchnaya-fantastika-50043902.html [in Ukrainian]

4. Duran, C.V. (2019, August). Moving beyond remittances to help the world's poor. World Economic Forum. URL: https://www.weforum.org/agenda/2019/08/cross-border-money-for-the-poor

5. Ward, O., Rochemont, S. (2019, March). Understanding Central Bank Digital Currencies (CBDC). An addendum to "A Cashless Society- Benefits, Risks and Issues (Interim paper)". Institute and Faculty of Actuaries. URL: https://www.actuaries.org.uk/documents/understanding-central-bank-digital-currencies-cbdc

6. Six central banks collaborate on central bank digital currencies. (2020, January). Ledger Insights. URL: https://www.ledgerinsights.com/six-central-banks-central-bank-digital-currencies-cbdc/

Received on 11.03.20 and updated on 16.03.20 